\title{
Rumen Digestive Capability of Zebu Steers in Wet and Dry
}

Seasons

R.M. HANSEN

\section{Abstract}

Most authors have suggested that the rumen's capability to digest foodstuff is influenced by the conditions resulting from microbial populations which are regulated by composition of the diets. Presumably the greatest ecological differences within the rumens of cattle grazing tropical semiarid range plants would be during wet and dry seasons. Rumen dry matter digestion indexes were determined by the nylon bag technique during wet and dry seasons for 4 different plant materials at the National Range Research Station near Kiboko, Kenya. The rumen digestive capability of 3 Zebu steers was not different between wet and dry seasons when these rumen fistulates selected their own foods from natural range vegetation.

Much confusion exists relative to the conditions within the rumen which allow normal digestion to occur. One assumption is that different kinds of diets may cause different rumen dry matter digestion (RDMD) rates. Most researchers using the nylon bag technique (Van Dyne 1962) have offered the rumen fistulates an assigned diet (Weakley et al. 1983) in order to minimize any variation between animals and/or dates that could be suspected to have been caused by diets.

At the National Range Research Station (NRRS) near Kiboko, Kenya, rumen fistulated animals during nylon bag digestion trials select their own diets while grazing range vegetation (Hansen et al. 1984). The general decline in nutritive value of forages with age is most obvious at the NRRS proceeding from "wet seasons" to "dry seasons." I have assumed in this study that the greatest diet difference would occur when rumen fistulates graze wet and dry season range vegetation.

The purpose of this paper is to present RDMD values obtained by the nylon bag technique at different times during wet and dry seasons of 1984. An objective was to rumen digest the same 4 plant

\footnotetext{
Author was range management specialist, Winrock International, Kenya National Range Research Station, P.O. Box 12, Makindu, Kenya.

Author's current address is Winrock International, Rte. 3, Morrilton, Arkansas 72110 .

Research was funded by a USAID grant to the Government of Kenya and published with approval of the Director of Research for the Ministry of Agriculture and Livestock Development.

Manuscript accepted 25 July 1985
}

JOURNAL OF RANGE MANAGEMENT 39(2), March 1986 materials in all of the trials and to compare the results to determine if the trials were different. General observations of results obtained during 1983 led me to hypothesize that there was no significant difference between RDMD indexes for wet and dry season trials.

\section{Methods}

Three rumen fistulated steers weighing about $300 \mathrm{~kg}$ were used in each trial. Two steers were Kenya Boran and one was East African Sahiwal. Throughout their life and during the 6 trials they grazed on bushed grasslands at the NRRS. Two trials were during the short dry season, 2 trials in the long dry season, 1 trial in the long wet season and 1 trial in the short wet season.

Four plant materials were tested during the 6 trials. Tests run in 1983 gave mean RDMD indexes that ranged from about $17 \%$ to $74 \%$ (Table 1). The test materials were the aboveground parts of a forb (Chrysanthemum cineariaefolium); the aboveground parts of a grass (Cynodon dactylon); leaves shed from a tree (Kigelia aethiopum); and the brown, shattered pods of a shrub (Leucaena leucocephala). All materials had been ground in a mill over a $1-\mathrm{mm}$ screen. At least 4 bags of each kind of plant material were placed in each rumen during each trial.

The procedures of Van Dyne (1962) and Quinton (1972) were followed. The nylon cloth bags were about $5 \mathrm{~cm} \times 10 \mathrm{~cm}$ in size. The cloth had no pores. There were 50 threads per $\mathrm{cm}$ and openings (pores) between the threads could not be seen using $400 \mathrm{X}$ magnification. This cloth was used to prevent solids from entering or leaving the nylon bags (Johnson et al. 1982). Prior to placement in the rumens each bag plus its contents $(2.0 \mathrm{~g})$ was oven dried at $65^{\circ} \mathrm{C}$ until no further weight loss before weighing to the nearest $0.01 \mathrm{~g}$.

After removal from the rumens, the 3 sets of samples for each trial were thoroughly washed and rinsed with tap water in the same large bucket. Previous trials had suggested that RDMD values from different rumens were alike if handled and washed in the same way. Without proof, I suspect that the greater differences between RDMD values between trials (about $5 \%$ ) than comparable values between different rumens in the same trial (about $1 \%$ ) are due to the thoroughness of washing. Because of the subjective judgment for detecting "no color" in rinse water, some variation probably results. Presumably most technicians cannot detect when all the solubles have been removed by this technique. The bags plus their residues after cleaning by washing were dried in an oven at $65^{\circ} \mathrm{C}$ until no further weight loss before weighing to the nearest $0.01 \mathrm{~g}$. 
Table 1. Some general chancteristics of the 4 forages used in nylon bag digestion trials.

\begin{tabular}{lrrr}
\hline \hline & \multicolumn{3}{c}{ Percentage \pm Standard Deviations } \\
\cline { 2 - 4 } Plant Materials & RDMD & $\begin{array}{c}\text { Crude } \\
\text { Protein }\end{array}$ & $\begin{array}{c}\text { Mineral } \\
\text { Ash }\end{array}$ \\
\hline $\begin{array}{l}\text { Chrysanthemum cineariae- } \\
\text { folium }\end{array}$ & $74.3 \pm 1.8$ & $11.3 \pm 0.1$ & $7.9 \pm 0.1$ \\
Cynodon dactylon & $58.5 \pm 3.6$ & $15.6 \pm 0.3$ & $13.2 \pm 0.1$ \\
Kigelia aethiopum & $57.3 \pm 1.6$ & $4.0 \pm 0.5$ & $32.8 \pm 1.3$ \\
Leucaena leucocephala & $16.8 \pm 2.9$ & $5.9 \pm 0.1$ & $5.9 \pm 0.2$ \\
\hline
\end{tabular}

'Average rumen dry matter digestion indexes estimated for trials in 1983.

$T$-tests and paired $t$-tests were used to determine statistically significant differences between means at the $95 \%$ confidence level.

\section{Results}

No statistically significant differences $(p>0.05)$ were found between comparable mean RDMD of the 3 rumen fistulates within a trial. Therefore, the mean percentage dry matter losses from each of the 4 plant materials were calculated across digestors for each trial date (Table 2). There were no differences $(p>0.05)$ in the mean RDMD indexes of any 1 of the 4 plant materials which appeared to have resulted from wet and dry season diets.

\section{Discussion}

The difference between animals during the same trial in RDMD averaged less than $1 \%$ and averaged $1.3 \%$ between comparable forages between the 6 trials. Presumably the small differences observed between animals and between trials were because of the thoroughness in extracting the solubles from the nylon bags and their rumen digested residues.

The type of rumen inoculum has been reported to affect in vitro digestion (Van Dyne 1962). The type of forage fed to the animal has been reported to influence in situ digestion of forages (Van Keuren and Heinemann 1962, Hopson et al. 1963, Uden et al. 1974, Weakley et al. 1983). However, Welch et al. (1983) detected no in vitro differences $(p>0.05)$ among the inocula of mule deer (Odocoileus hemionus), elk (Cervus elaphus nelsoni), pronghorn (Antilocapra americana), cattle (steers), goats (nannies), and domestic sheep (ewe lambs). He reported that the sheep and cattle were being fattened on a diet of alfalfa hay, rolled barley, corn and pasture, goats were fed only a maintenance ration of alfalfa hay and pasture, and the rumen fluids of the mule deer were from native fall ranges and those of elk and pronghorn from native winter ranges.
At the NRRS the RDMD values of diets collected using esophageal fistulated cattle grazing bushed grasslands have varied between 65 and $75 \%$ in the wet seasons and have been about $55 \%$ in the dry seasons before the rains come. In my study I assume the fistulates were adapted to the range vegetation of the NRRS, as opposed to having to comply with human choices within a metabolic laboratory. Much of the uniformity between digestors during the same trial and between trials at different seasons could have resulted from the ability of the test animals to select a uniform diet of the highest quality available.

The rankings of forage digestibilities determined by in vivo and in vitro procedures seems to be nearly the same (Welch et al. 1983). Certain authors have emphasized statistically significant differences in forage digestion indexes even when the biological importance was minimal or even nutritionally unimportant. The major conclusion of this study is that the rumen digestive capability of cattle may vary little between seasons provided the digestor is able to select its own food from natural range vegetation. Because intake and passage rates are reduced as the fiber fraction increases at the end of a growing season, true digestion rates are lower at this time than they are during other periods. Additional research is needed in order to settle controversy about the variation in intraruminal conditions for animals penned versus those selecting forages from a range ecosystem.

\section{Literature Cited}

Hansen, R.M., D.L. Whittington, R.D. Child, and J.M. Wanyama. 1984. Ruminal digestion consistency of Zebu cattle. J. Range Manage. 37:283-284

Hopson, J.D., R.R. Johnson, and B.A. Dehority. 1963. Examination of the dacron bag technique and a method for measuring cellulose digestibility and rate of forage digestion. J. Anim. Sci. 22:448-453.

Johnson, M.K., H. Wofford, and W. Mitchell. 1982. Contamination during nylon-bag digestion trials. J. Wildl. Manage. 46:253-255.

Quinton, D.A. 1972. Standardization of the nylong bag technique and its use in nutritive evaluation of northeastern Colorado range sites. Ph.D. Diss., Colorado State Univ., Fort Collins.

Uden, P., R. Parra, and P.J. Van Soest. 1974. Factors influencing reliability of the nylon bag technique. J. Dairy Sci. 57:622.

Van Dyne, G.M. 1962. Micro-methods for nutritive evaluation of range forages. J. Range Manage. 15:303-314.

Van Keuren, R.W., and W.W. Heinemann. 1962. Study of a nylon bag technique for in vivo estimation of forage digestibility. J. Anim. Sci. 21:340-345.

Weakley, D.C., M.D. Stern, and L.D. Satter. 1983. Factors affecting disappearance of feedstuff from bags suspended in the rumen. J. Anim. Sci. 56:493-507.

Welch, B.L., J.C. Pederson, and W.P. Clary. Ability of different rumen inocula to digest range forages. J. Wildl. Manage. 4:873-877.

Table 2. Mean percentage ( \pm standard error) dry matter loss from 4 plant materials digested in the rumens of 3 Zebu steers by the nylon bag technique on different dates while grazing bushed grasslands at the Kenya National Range Research Station, Kiboko.l

\begin{tabular}{|c|c|c|c|c|}
\hline $\begin{array}{l}\text { Dates and Seasons } \\
\text { Number of Samples }\end{array}$ & $\begin{array}{l}\text { Chrysanthemum } \\
\text { cineariaefolium }\end{array}$ & Cynodon dactylon & Kigelia aethiopum & $\begin{array}{l}\text { Leucaena } \\
\text { leucocephala }\end{array}$ \\
\hline $\begin{array}{l}28 / 03 / 84, \text { dry season } \\
\mathrm{N}=20\end{array}$ & $73.2 \pm 0.7 \mathrm{a}$ & & $56.3 \pm 0.5 b$ & $18.2 \pm 0.7 b$ \\
\hline $\begin{array}{l}05 / 04 / 84, \text { dry season } \\
N=30\end{array}$ & $74.9 \pm 0.3 \mathrm{~cd}$ & $58.7 \pm 0.5 b c$ & $58.1 \pm 0.4 \mathrm{a}$ & $16.7 \pm 0.9 \mathrm{ab}$ \\
\hline $\begin{array}{l}15 / 05 / 84, \text { wet season } \\
N=20\end{array}$ & $73.4 \pm 0.5 \mathrm{ab}$ & $56.9 \pm 0.5$ & & $16.2 \pm 0.9 \mathrm{ab}$ \\
\hline $\begin{array}{l}10 / 07 / 84, \text { dry season } \\
N=16\end{array}$ & $74.4 \pm 0.7 \mathrm{abc}$ & $57.8 \pm 0.8 \mathrm{c}$ & $57.6 \pm 0.7 \mathrm{ab}$ & $17.0 \pm 0.5 \mathrm{ab}$ \\
\hline $\begin{array}{l}30 / 09 / 84, \text { dry season } \\
N=18\end{array}$ & $75.4 \pm 0.9$ abcde & $60.6 \pm 1.0 \mathrm{ab}$ & & $16.5 \pm 0.9 \mathrm{ab}$ \\
\hline $\begin{array}{l}25 / 11 / 84, \text { wet season } \\
N=18\end{array}$ & $75.3 \pm 0.3$ cde & $61.6 \pm 0.7 a$ & $54.5 \pm 0.5$ & $16.0 \pm 0.3 \mathrm{a}$ \\
\hline
\end{tabular}

${ }^{1}$ Means of the same forage and column with a common suffix are not statistically different at the $95 \%$ confidence level. 